\title{
Pericarp ontogeny of Tapirira guianensis Aubl. [Anacardiaceae) reveals a secretory endocarp in young stage
}

\author{
Elisabeth Emilia Augusta Dantas Tölke ${ }^{\star *}$, Ana Paula Stechhahn Lacchia² ${ }^{2}$ Diego Demarco ${ }^{3}$ and Sandra Maria \\ Carmello-Guerreiro'
}

Received: August 9, 2016

Accepted: October 6, 2016

\begin{abstract}
Most species of Anacardiaceae have drupes containing secretory structures.. The substances produced by these structures may have importance to industry and folk medicine, and may even cause allergenic effects. This work describes the ontogeny of pericarp of Tapirira guianensis with an emphasis on the secretory structures present at different stages of development. Ovary and fruits in various stages of development were collected, fixed and processed for studies using light and scanning electron microscopy according to conventional techniques. Histochemical tests were employed to identify the major metabolites present in the tissues. The fruit is a drupe formed by exocarp, mesocarp containing secretory ducts and idioblasts, and endocarp with some lignified layers. Fruit growth occurs through the division and elongation of cells. The secretory ducts produce mainly phenols and lipids and are active during all stages of development. The secreted substances protect the fruit against pathogens and predators. In ripe fruits the cells of the mesocarp accumulate starch. This study is the first report of the presence of a secretory endocarp in young fruits of a species of Anacardiaceae. The substances produced by the endocarp in early developmental stages may play an important role in seed dispersal and germination.
\end{abstract}

Keywords: cashew family, drupe, fruit, mucilages, secretory ducts

\section{Introduction}

Most species of Anacardiaceae have drupaceous fruits (Wannan \& Quinn 1990; Gonzalez \& Vesprini 2010). Wannan \& Quinn (1990) studied fruits belonging to 29 genera of Anacardiaceae and recognized two basic types of endocarp: (1) the Spondias type - consisting of a mass of sclerenchyma with irregular orientation and (2) the Anacardium type - characterized by a lignified inner epidermis and a layered arrangement, including sclereids in palisade. The first type occurs in Spondioideae tribe and the second type in Anacardioideae tribe (Wannan \& Quinn 1990; Pell et al. 2011).

Secretory structures are quite common in fruits of Anacardiaceae (Von-Teichman 1987; Wannan \& Quinn 1990; Carmello-Guerreiro \& Paoli 2000; 2002; 2005; Machado \& Carmello-Guerreiro 2001; Lacchia \& Carmello-Guerreiro 2009; González \& Vesprini 2010). The most frequent structures are the ducts and cavities, both of which may

\footnotetext{
${ }^{1}$ Programa de Pós-Graduação em Biologia Vegetal, Departamento de Biologia Vegetal, Instituto de Biologia, Universidade Estadual de Campinas, 13083-970, Campinas, SP, Brazil

${ }^{2}$ Departamento de Biologia, Centro de Ciências Biológicas e da Saúde, Universidade Estadual da Paraíba, campus I, 58429-600, Campina Grande, PB, Brazil

${ }^{3}$ Departamento de Botânica, Instituto de Biociências, Universidade de São Paulo, 05508-090, São Paulo, SP, Brazil
}

* Corresponding author: elisabeth.tolke@gmail.com 
produce resin, gum or a mixture of substances (Venning 1948; Metcalfe \& Chalk 1950; Lacchia \& Carmello-Guerreiro 2009). According to Barroso et al. (2007), the mesocarp of the representatives of this family can be fleshy (Mangifera and Spondias) or spongy with ducts or cavities (e.g., Anacardium, Astronium and Myracrodruon). In the latter, the secretory system is quite developed, and the ducts or cavities occupy almost the entire mesocarp (CarmelloGuerreiro \& Paoli 2000). The substances produced may have importance in industry and folk medicine and can even cause allergenic effects (Dong \& Bass 1993; Barroso et al. 2007; Pell et al. 2011).

Idioblasts (Carmello-Guerreiro \& Paoli 2005), glandular trichomes (Li et al.1999) and pericarpial nectaries may also occur (Wunnachit et al. 1992; Rickson \& Rickson 1998). These nectaries are already present in flowers and are maintained in the fruits, improving the viability and seed dispersal. None of these structures are exclusive to secreting fruits but basically occur in the whole plant (Lacchia \& Carmello-Guerreiro 2009; Lacchia et al. 2016a; 2016b).

Tapirira belongs to tribe Spondioideae of Anacardiaceae (Pell et al. 2011). This genus includes about eight species of trees occurring mainly in tropical areas of America (Wendt \& Mitchell 1995; Tropicos 2016). Tapirira guianensis is widely distributed throughout Brazil and other countries of South and Central America (Tropicos 2016), especially in areas of moist soil (Santana et al. 2009). It is a dioecious, important species for logging, medicinal use and may be employed in the recovery of degraded areas and riparian forests (Lorenzi 2002; Lenza \& Oliveira 2005; Santana et al. 2009). The drupes of this species are greatly appreciated by birds (Corrêa 1978). Von-Teichman (1990) conducted an anatomical study of the ripe fruit of this species, which is classified as Spondias type. However, despite describing them, the author does not emphasize the secretory structures.

Therefore, this study aimed to examine the ontogeny of the pericarp of Tapirira guianensis with an emphasis on secretory structures present in different stages of development. Through histochemical tests the secretion produced by different structures, in different stages of development, was characterized. We also describe the first case of a secretory endocarp in Anacardiaceae.

\section{Materials and methods}

\section{Plant material}

Anthetic female flowers and fruits at various developmental stages of Tapirira guinanensis Aubl. were collected in three areas in the state of São Paulo, Brazil: the Itirapina experimental station $\left(22^{\circ} 13^{\prime} \mathrm{S} ; 47^{\circ} 51^{\prime} \mathrm{W}\right)$, the Mogi Guaçu experimental station ( $22^{\circ} 10^{\prime} \mathrm{S} ; 4^{\circ} 07^{\prime} \mathrm{W}$ ) and an additional area of cerrado (Brazilian savannah) in the District of Sousas, Campinas (22 $51^{\prime} S$; $46^{\circ} 57^{\prime} \mathrm{W}$ ). The Itirapina experimental station includes vegetation of Cerrado and Campo Cerrado, while the Mogi Guaçu experimental station comprises sensu lato Cerrado vegetation, according to the classification of Ribeiro \& Walter (1998). Collections were made from March to December 2011 and from January to February 2012. Vouchers are deposited in the UEC herbarium (UEC 182229).

\section{Light microscopy (LM)}

For anatomical studies the samples were fixed in FAA (formaldehyde, acetic acid, 50\% ethanol) for $24 \mathrm{~h}$ (Johansen 1940). The material was then dehydrated in an ethanol series and embedded in hydroxyethyl methacrylate resin (Historesin ${ }^{\circledR}$ Leica), according to Gerrits \& Smid (1983). Transverse and longitudinal sections $8 \mu \mathrm{m}$ thick were obtained using a Microm HM340E rotary microtome and stained with $0.05 \%$ Toluidine Blue in sodium acetate buffer with a $\mathrm{pH}$ of 4.7 (O'Brien et al. 1964). All slides were mounted with water and the images captured with an Olympus DP71 digital camera coupled to an Olympus BX51 microscope.

\section{Histochemistry}

For the histochemical tests, the material was fixed in FAA (for hydrophilic substances) for $24 \mathrm{~h}$ (Johansen 1940) and in BNF (buffered neutral formalin, for lipophilic and phenolic substances) for $48 \mathrm{~h}$ (Lillie 1965). The material was then also dehydrated in an ethanol series and embedded in hydroxyethyl methacrylate resin (Gerrits \& Smid 1983). Transverse and longitudinal sections $8 \mu \mathrm{m}$ thick were obtained using a Microm HM340E rotary microtome. The treatments performed can be found in Table 1 . The results were recorded using an Olympus DP71 digital camera coupled to an Olympus BX51 microscope.

\section{Scanning electron microscopy (SEM)}

For micromorphological analysis, samples fixed in FAA were dehydrated in an ethyl series, critical point dried, and sputter coated with gold. Observations were carried out using a Jeol JSM 5800 LV scanning electron microscope at $10 \mathrm{kV}$ equipped with a digital camera.

\section{Stages of development}

Based on the anatomical changes that occur during fruit development, the results were grouped into four stages: (i) ovary of the anthetic flower, (ii) very young fruit (3-5 mm in length), (iii) immature fruit with verified elongation or cell growth (5.1-8 $\mathrm{mm}$ in length) and (iv) ripe fruit (8.1-10 $\mathrm{mm}$ in length) (Fig. 1). The pericarp is divided into three clearly differentiated parts in all phases of development: exocarp, mesocarp and endocarp. 


\section{Results}

\section{Stage /}

The outer epidermis of the ovary is uniseriate (Fig. 2AB), composed of juxtaposed cells coated with a thick cuticle and containing stomata (Fig. 2B). The ovary is covered with glandular and tector trichomes (Fig. 2C-F). The glandular trichomes contain a bicellular, uniseriate stalk while the secretory head is multicellular and multiseriate (3-4 rows) (Fig. 2E). The non-glandular trichomes are elongated, multicellular and uniseriate with tapered apex and thick wall (Fig. 2F). The ordinary epidermal cells and secretory trichomes accumulate phenolic substances (Fig. 2G, Tab.2). Furthermore, the trichomes showed a positive reaction to lipids and polysaccharides (Tab.2).

The ovarian mesophyll can be divided into three regions based on the size and arrangement of the cells. The outermost region underlying the external ovarian epidermis consists of parenchyma cells in an intense process of cell division (Fig.2A). This region consists of eight to ten layers of cells with evident nuclei and thin walls (Fig. 2A-B). Druses are distributed throughout this region (Fig.2A). The middle portion contains vascular bundles and secretory ducts (Fig.2A). The secretory ducts have a one layered epithelium (Fig. 2H) which releases a secretion into the lumen formed by droplets and a more fluid portion composed of lipids, phenolic compounds and mucilage (Tab.2). The internal region of the ovarian mesophyll consists of 12-15 cell layers of parenchyma in an intensive process of division (Fig. 2A) with evident nuclei and thin cell walls.

The inner epidermis of the ovary is uniseriate, formed by juxtaposed cells with evident nuclei in central position (Fig. 2I). These cells undergo periclinal divisions forming a biseriate inner epidermis (Fig. 2I).

\section{Stage /l}

At this stage the increase of pericarp layers primarily occurs. The exocarp, derived from the ovarian outer epidermis, is quite similar to the previous stage (Fig. 3A), except that a significant loss of trichomes occurs.

The mesocarp develops from the fundamental ovarian tissue and is divided into three zones: outer, median and

Table 1. Histochemical tests used in the characterization of the substances.

\begin{tabular}{|l|c|}
\hline Test & Substance detected \\
\hline Sudan black B (Pearse 1980) & lipids \\
\hline Nile blue (Cain 1947) & acidic and neutral lipids \\
\hline Lugol's reagent (Johansen 1940) & starch \\
\hline Ferric chloride (Johansen 1940) & phenolic compounds \\
\hline Wagner's reagent (Furr \& Mahlberg 1981) & alkaloids \\
\hline Schiff's reagent (PAS) (McManus 1948) & carbohydrates \\
\hline Ruthenium red (Gregory \& Baas 1989) & acidic mucilages \\
\hline Tannic acid and ferric chloride (Pizzolato \& Lillie 1973) & mucilages \\
\hline Copper acetate and rubeanic acid (Ganter \& Jollés 1969; 1970) & fatty acids \\
\hline Aniline blue black (Fisher 1968) & proteins
\end{tabular}
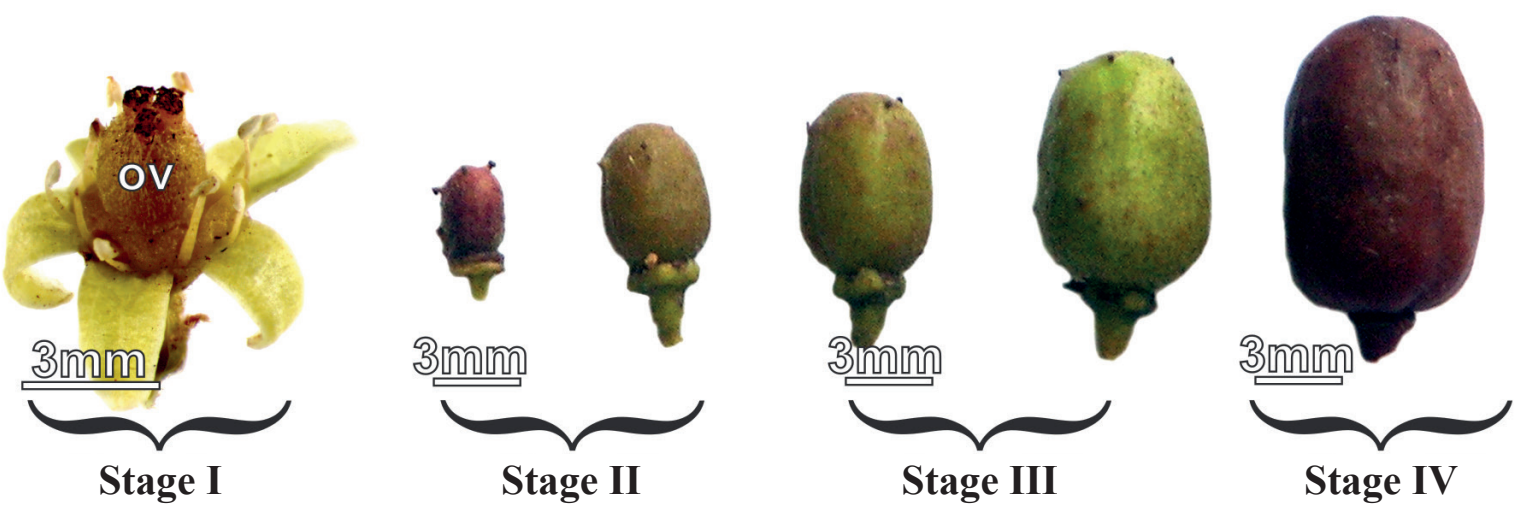

Figure 1. Stages of development of Tapirira guianensis fruit under stereomicroscope. Stage I: ovary of the anthetic flower, Stage II: very young fruit (3-5 mm in length), Stage III: immature fruit with verified elongation or cell growth (5.1-8 mm in length) and Stage IV: ripe fruit (8.1-10 $\mathrm{mm}$ in length). 


\section{Elisabeth Emilia Augusta Dantas Tölke, Ana Paula Stechhahn Lacchia, Diego Demarco and Sandra Maria Carmello-Guerreiro}

Table 2. Histochemical tests in Tapirira guianensis fruits at different stages of development.

\begin{tabular}{|c|c|c|c|c|c|c|c|}
\hline Test & $\begin{array}{l}\text { outer epidermis/ } \\
\text { epicarp }\end{array}$ & $\begin{array}{l}\text { glandular } \\
\text { trichomes }\end{array}$ & $\begin{array}{l}\text { outer } \\
\text { mesocarp }\end{array}$ & $\begin{array}{l}\text { median } \\
\text { mesocarp }\end{array}$ & $\begin{array}{l}\text { inner mesocarp } \\
\text { [idioblasts] }\end{array}$ & endocarp & secretory ducts \\
\hline Sudan black B & - & $+(\mathrm{I}, \mathrm{II})$ & - & - & - & $+(\mathrm{II})$ & + (I, II, III, IV) \\
\hline Nile blue & - & $+(\mathrm{I}, \mathrm{II})$ & - & - & - & $+(\mathrm{II})$ & + (I, II, III, IV) \\
\hline Lugol's reagent & - & - & $+(\mathrm{IV})$ & $+(\mathrm{IV})$ & - & - & - \\
\hline Ferric chloride & + (I, II, III, IV) & $+(\mathrm{I}, \mathrm{II})$ & - & - & + (II, III) & - & + (I, II, III, IV) \\
\hline Wagner's reagent & - & - & - & - & - & - & - \\
\hline Schiff's reagent (PAS) & - & $+(\mathrm{I}, \mathrm{II})$ & - & - & - & $+(\mathrm{II})$ & + (I, II, III, IV) \\
\hline Ruthenium red & - & - & - & - & - & - & + (I, II, III, IV) \\
\hline Tannic acid and ferric chloride & - & - & - & - & - & - & + (I, II, III, IV) \\
\hline Copper acetate and rubeanic acid & - & - & - & - & - & - & - \\
\hline Aniline blue black & - & - & - & - & - & - & - \\
\hline
\end{tabular}

Notes: I (stage I), II (stage II), III (stage III), IV (stage IV), + (positive reaction), - (negative reaction).

inner mesocarp (Fig. 3A). In the outer mesocarp, there is an increased number of layers, which comprise about 20 layers of parenchyma cells, which are still in the process of cell division in several planes. In median mesocarp the secretory ducts are distributed. In this phase the secretory ducts are delimited by a one layered epithelium surrounded by a sheath (2-3 layers) (Fig. 3B). The secretion responded positively to lipids, total polysaccharides, phenolic compounds and mucilage (Fig. 3C-F) (Tab.2). The epithelial cells degenerate adding to part of the secretion (Fig. 3G), while the sheath cells undergo periclinal divisions renewing the epithelium. In the inner mesocarp, idioblasts with phenolic content appear (Fig. 3H) (Tab.2). This region presents cell divisions in several levels.

The endocarp, derived from inner ovarian epidermis, consists of two layers of secretory cells (4A-D). Under SEM, several drops of secretion were observed in the endocarp (Fig. 4E), which were also observed on the developing seed coat (Fig. 4F). The endocarp secretion responded positively to lipids, mucilages and polysaccharides tests (Fig. 4A-D) (Tab.2).

\section{Stage /II}

At this stage, all trichomes of the exocarp are lost. The cells of the outer mesocarp present pectic-cellulosic thickening becoming collenchymatous (Fig. 5A-B), the thickest being close to the exocarp (Fig. 5B). The median mesocarp increases the parenchyma cell layers between the secretory ducts and the vascular bundles, now welldeveloped (Fig. 5A). In the inner mesocarp, the most striking differences arise. Intercellular spaces become quite conspicuous among the parenchyma cells (Fig. 5C). In the last 3-4 layers, the vast majority of internal mesocarp cells differentiates, forming elongated sclereids in longitudinal, transverse and oblique directions (Fig. 5C). The cells that do not lignify remain parenchymatic with many containing crystals (Fig. 5C). In the endocarp, the layer adjacent to the inner mesocarp differs in elongated sclereids with the last layer, in contact with the locule, remaining non-lignified (Fig. $5 C)$. In this phase, the endocarp is not secretory; however, secretions produced in the previous stage remain covering the entire endocarp and seed coat.

\section{Stage IV}

The most evident change in the ripe fruit exocarp is the appearance of lenticels (Fig. 6A). The external and median mesocarp cells accumulate starch (Fig. 6B-C) (Tab.2). Parenchyma cells in the median mesocarp layers divide and stretch in several directions (Fig. 6D). In the inner mesocarp, some of the idioblasts that accumulated phenolic compounds are now differentiated in sclereids (Fig. 6E). In the endocarp, the layer in contact with the locule (which was secretory) now also lignifies, forming sclereids (Fig. 6F).

\section{Discussion}

The fruit of T. guianensis is classified as a drupe since the exocarp and mesocarp are fleshy and, the endocarp is formed by several layers of sclerified cells (Von-Teichman 1990). In drupes, the exocarp acts as a protective outer layer, the mesocarp is usually parenchymal and endocarp is hard, with layers that protect the seed (Roth 1977; Spjut 1994). According to Roth (1977), the exocarp and the endocarp may be formed by a single layer derived from the outer and the inner ovarian epidermis, respectively. In this case, they are called sensu stricto exocarp or endocarp. When they also include derived mesocarp layers, they are called sensu lato exocarp or endocarp. The exocarp of T. guianensis is formed by the outer layer, derived from the outer epidermis of the ovary, and by several layers of collenchymatous cells formed from the outer mesocarp. Therefore, in this species the exocarp is known as sensu lato, according to Roth (1977). 

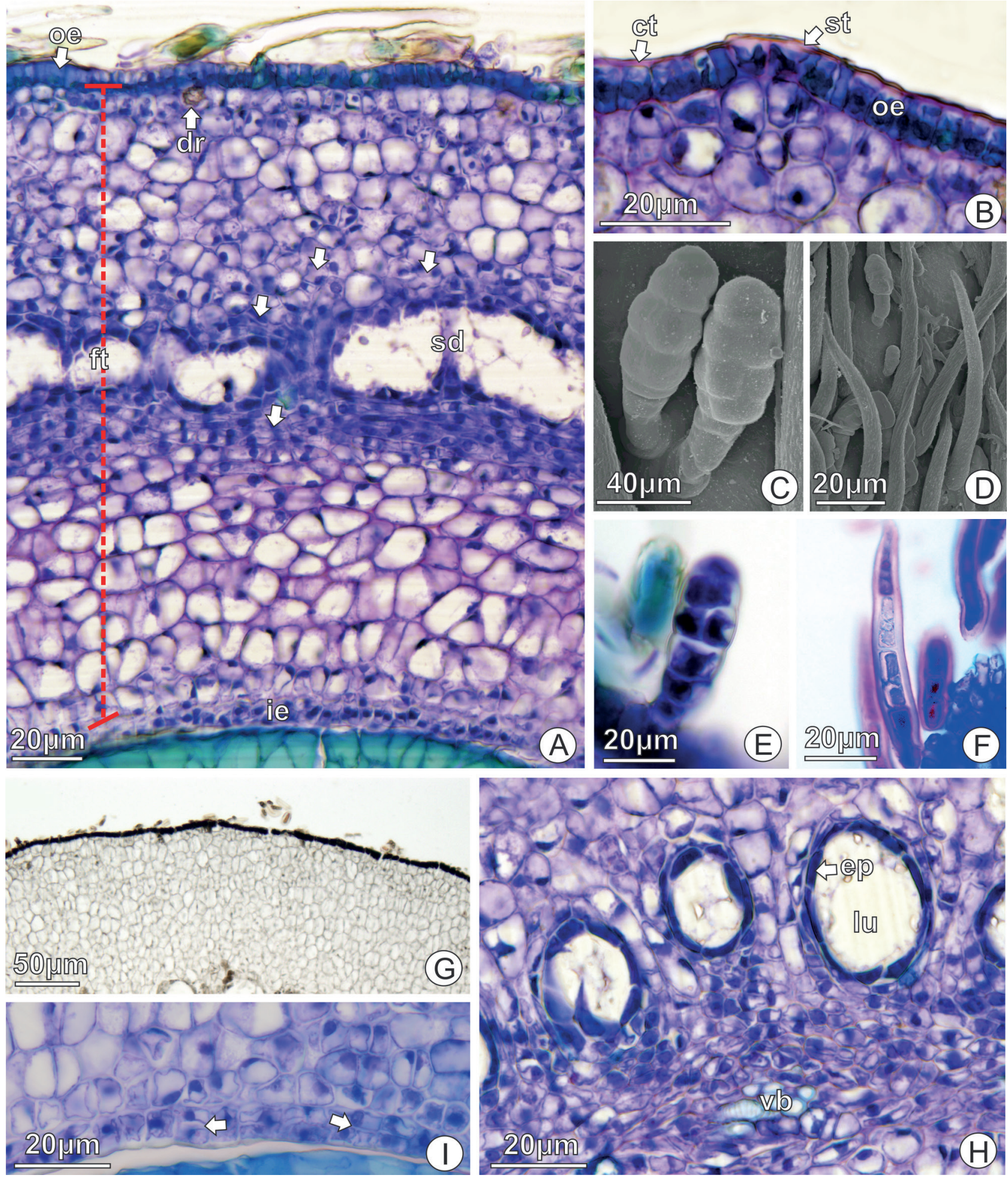

Figure 2. Structural and histochemical aspects of Tapirira guianensis ovary. (A) General aspect of the ovary in longitudinal-section. Note the cells in intense process of division (arrows). (B) Outer epidermis of the ovary in cross-section. (C-D) Electron micrographs of trichomes in the outer epidermis. (E) Glandular trichome in longitudinal section. Note the bicellular and uniseriate stalk and the multicellular and multiseriate secretory head (F) Elongated, multicellular and uniseriate non-glandular trichome in longitudinal section. (G) Outer epidermis showing positive reaction to ferric chloride. (H) Fundamental tissue in cross-section showing the secretory ducts and vascular bundles still in development. The secretory ducts have an epithelium which releases a secretion into the lumen. (I) Inner epidermis in cross-section showing the periclinal divisions (arrows). Abbreviations: ct, cuticle; dr, druse; ep, epithelium; ft, fundamental tissue; ie, inner epidermis; lu, lumen; oe, outer epidermis; sd, secretory duct; st, stomata; vb, vascular bundle. 

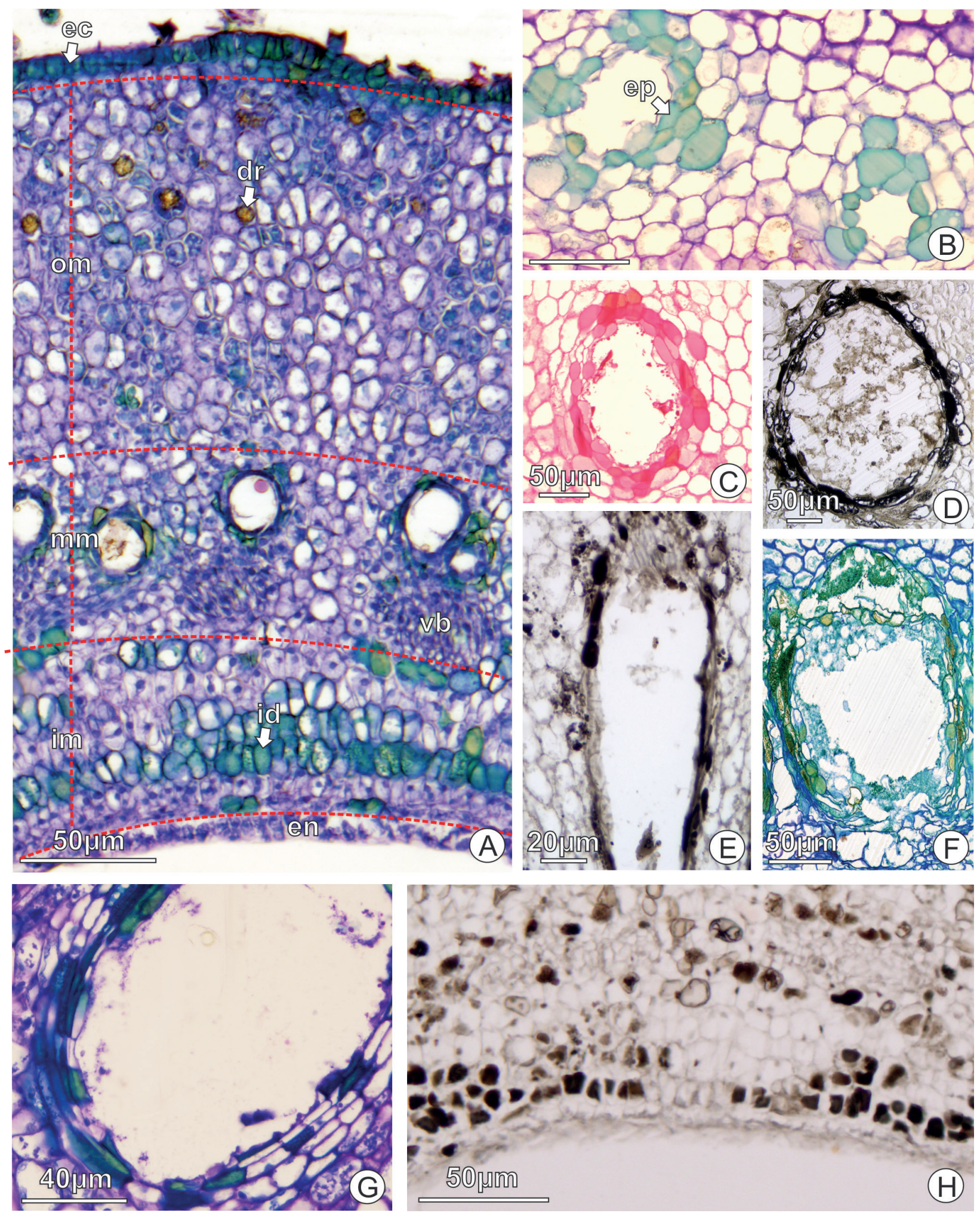

Figure 3. Structural and histochemical aspects of Tapirira guianensis pericarp in Stage II. (A) General aspect of the pericarp in crosssection. (B) Detail of the secretory ducts with uniseriate epithelium and multiseriate sheath. (C) Secretory duct showing positive reaction to Schiff reagent. (D) Secretory duct showing positive reaction to Sudan black B. (E) Secretory duct showing positive reaction to ferric chloride. (F) Secretory duct showing positive reaction to Nile blue sulphate. (G) Detail of the epithelium. Note the degeneration of cells, eliminated together with the secretion, while the sheath cells undergo periclinal divisions renewing this epithelium. (H) Idioblasts showing a positive reaction to ferric chloride Abbreviations: dr, druse; ec, exocarp; en, endocarp; ep, epithelium; id, idioblast; im, inner mesocarp; mm, median mesocarp; om, outer mesocarp; vb, vascular bundle. 

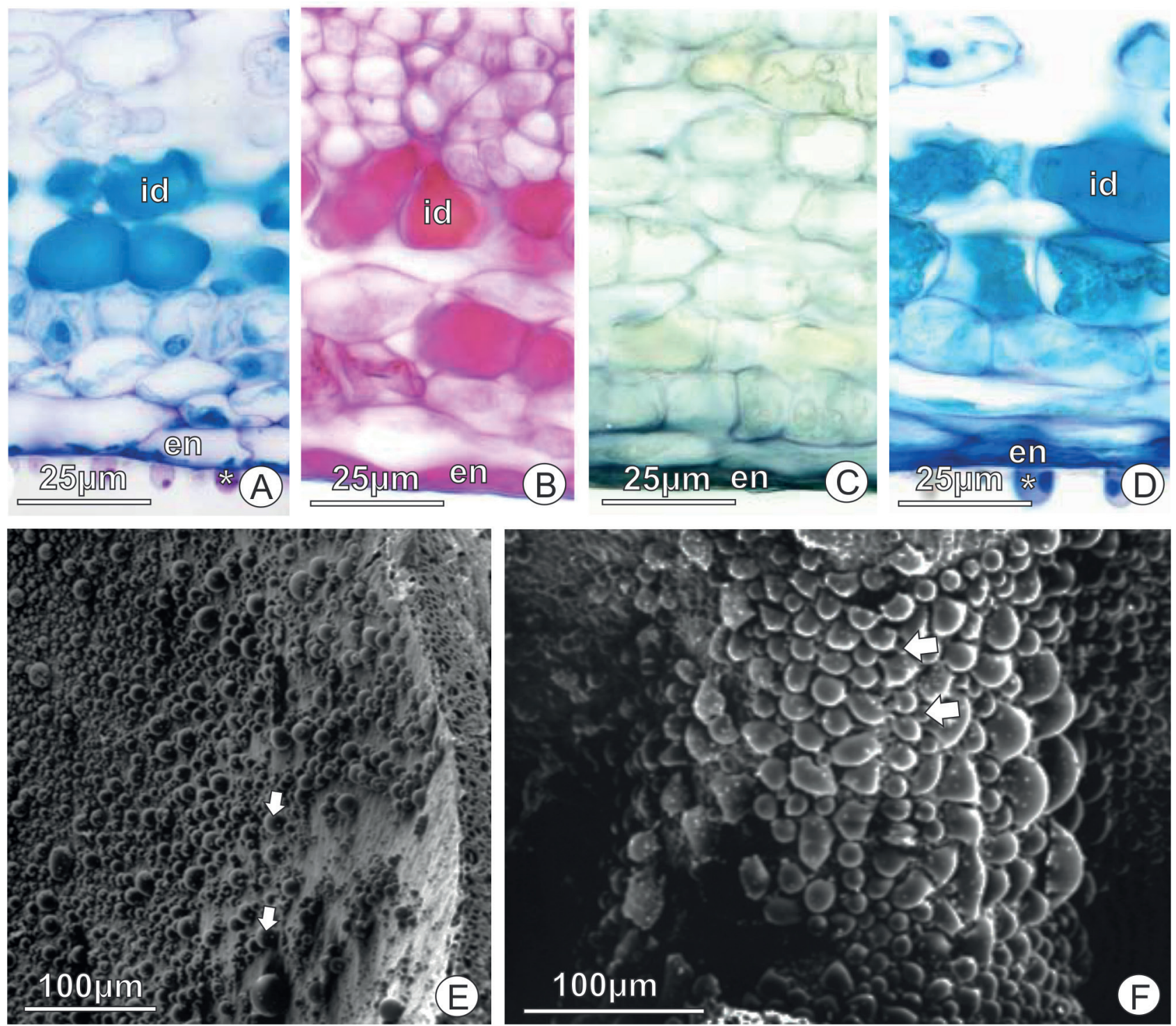

Figure 4. Histochemical and SEM of the endocarp in Stage II. (A) Endocarp and idioblasts in Toluidine blue coloration. Note the secretion droplets $\left(^{*}\right)$. (B) Endocarp and idioblasts showing positive reaction to Schiff reagent. (C) Endocarp showing positive reaction to tannic acid and ferric chloride. (D) Endocarp and idioblasts showing positive reaction to Nile blue sulphate. Note the secretion droplets $\left(^{*}\right)$. (E) Electron micrograph of secretion droplets (arrow) in endocarp. (F) Electron micrograph of secretion droplets (arrow) in funicle. Abbreviations: en, endocarp; id, idioblast

Von-Teichman (1990), despite having studied just the ripe fruit, also considers the exocarp of this species as sensu lato. In this case the external mesocarp is considered part of the exocarp due to their functional aspect (Roth 1977). In general, the exocarp of the Spondioideae representatives, a tribe belonging to $T$. guianensis, consists of small, thin walled, tightly packed parenchyma cells, which may develop thick cellulosic walls (Wannan \& Quinn 1990). In Anacardioideae, the exocarp may be sclerified, e.g., Lithraea molleoides (Carmello-Guerreiro \& Paoli 2005) and Schinus terebinthifolius (Carmello-Guerreiro \& Paoli 2002). The ovarian epidermis and developing fruit are covered by tector and glandular trichomes. This characteristic was not observed by Von-Teichman (1990) since he studied only the ripe fruits. The trichomes play an important role in mechanical protection of the fruit in development, and also act in protection against ultraviolet radiation (Roth 1977). This protection is enhanced by phenolic compounds produced by the epidermis and the glandular trichomes (Castro \& Demarco 2008), these substances assist in protection against herbivory (Fahn 1979; Calvo et al. 2010) and against the microorganism proliferation (Calvo et al. 2010).

Secretory ducts are widely distributed in the median region of the mesocarp. They play an important role during all phases since they remain active during 

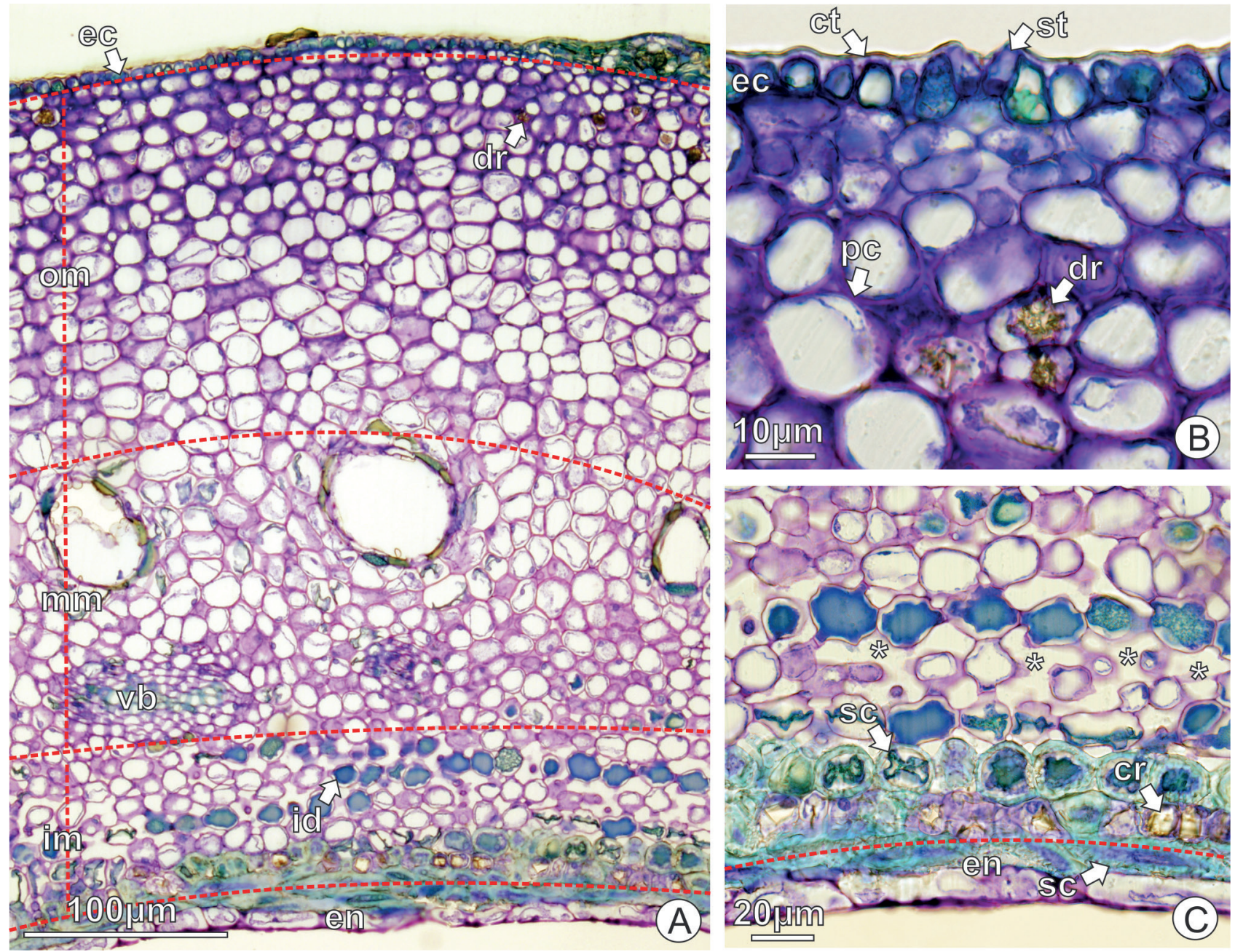

Figure 5. Structural aspects of Tapirira guianensis pericarp in Stage III. (A) General aspect of the pericarp in cross-section. (B) Exocarp and outer mesocarp in cross-section. Note the pectic-cellulosic thickening and druses. (C) Detail of inner mesocarp and endocarp. Note intercellular spaces $\left(^{*}\right)$ and the formation of sclereids. The layer in contact with the locule, remaining non-lignified. Abbreviations: cr, crystal; ct, cuticle; dr, druse; ec, exocarp; en, endocarp; id, idioblast; im, inner mesocarp; mm, median mesocarp; om, outer mesocarp; pc, pectic-cellulosic thickening; sc, sclereid; st, stomata; vb, vascular bundle.

the whole fruit development. They produce the same substances independent of the phase in which the fruit is. In Anacardiaceae several studies have mentioned the presence of resiniferous ducts in fruits, always associated with vascular bundles (Von-Teichman 1987; 1990; Wannan \& Quinn 1990; Von-Teichman \& Van-Wyk 1993; 1994; 1996; Carmello-Guerreiro \& Paoli 2000; 2005; Machado \& Carmello-Guerreiro 2001; González \& Vesprini 2010). This is a constant feature for the family, regardless of the tribe to which the species belong.

Lacchia \& Carmello-Guerreiro (2009) closely studied the formation of these ducts in T. guianensis fruit, as well as the secretory mechanism. The authors concluded that the formation of the ducts is schizogenous and the secretory mechanism is eccrine. These ducts have a mixed secretion, containing lipids, polysaccharides and phenolic substances. It is possible to verify the disruption of the epithelium cells and consequently extravasation of the secretion into the lumen with cell debris with continuous replacement of the epithelium by the meristematic activity of the sheath, which characterizes the mode of secretion as holocrine. The occurrence of a parenchymatous sheath surrounding secretory ducts producing new epithelium cells has been reported in several studies (Monteiro et al. 1995; 1999; Machado \& Carmello-Guerreiro 2001; Bennici \& Tani 2004; Rodrigues et al. 2011a; 2011b).

The large amount of phenolic substances found in $T$. guianensis fruit, stored in ducts, exocarp and idioblasts, is also found in other species of the family, referred to as tanniferous substances (Von-Teichman 1987; Von-Teichman \& Van-Wyk 1993; 1994; 1996; Piennar \& Von-Teichman 1998; González \& Vesprini 2010). Von-Teichman (1990) also report these substances in ducts and idioblasts of T. guianesis fruits. However, it does not perform tests to confirm the chemical nature of these substances. There are several functions of the phenolic substances, among 

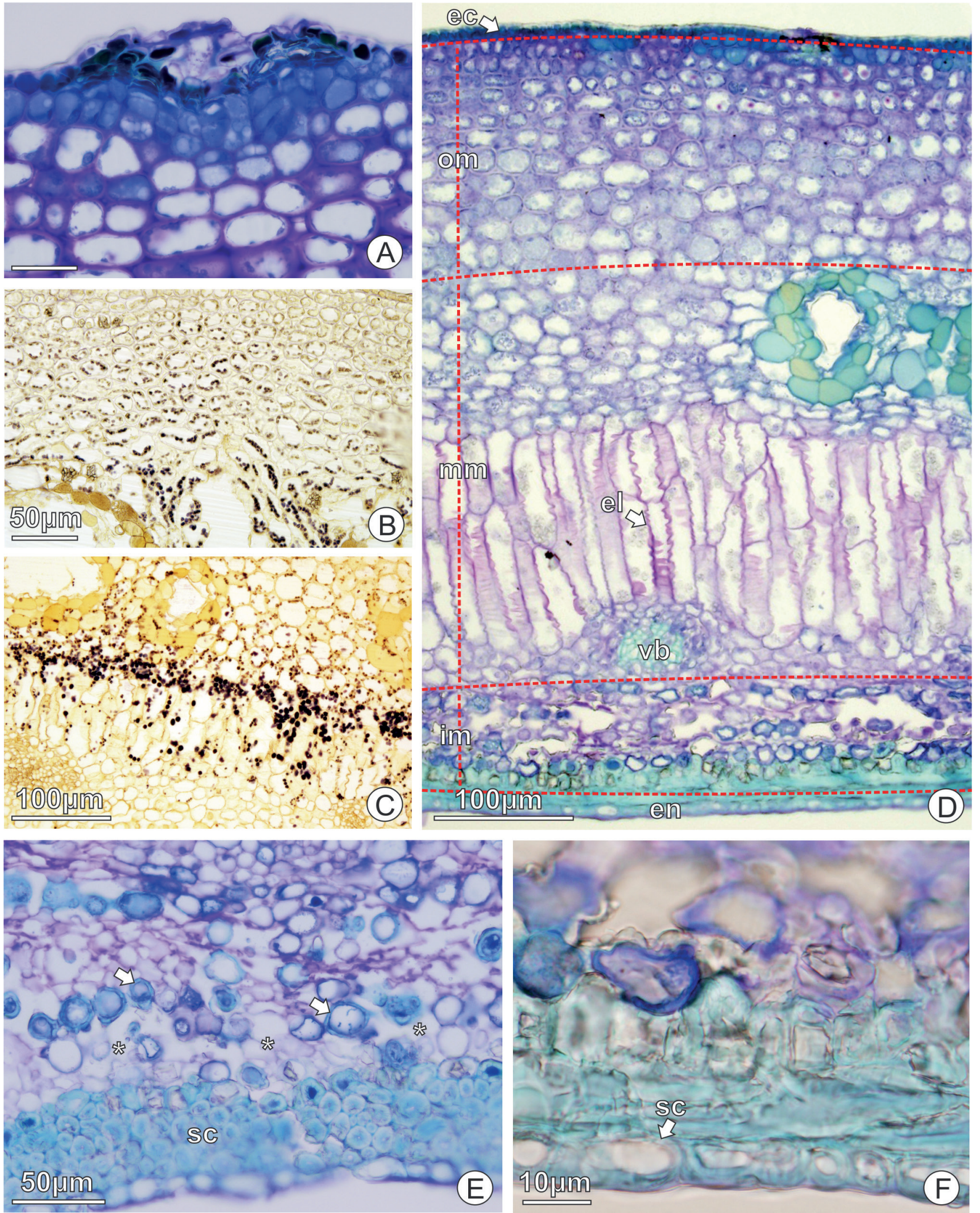

Figure 6. Structural and histochemical aspects of Tapirira guianensis pericarp in Stage IV. (A) Lenticel formation in cross-section. (B) Outer mesocarp showing positive reaction to Lugol. (C) Median mesocarp showing positive reaction to Lugol. (D) General aspect of the fruit in cross-section. (E) Detail of inner mesocarp and endocarp. Note intercellular spaces $\left(^{*}\right)$ and the fact that some of the cells that accumulated phenolic compounds now are differentiated sclereids (arrows). (F) Endocarp. Note that the layer in contact with the locule now also lignifies. Abbreviations: ec, exocarp; el, elongated cell; en, endocarp; im, inner mesocarp; mm, median mesocarp; om, outer mesocarp; sc, sclereid; vb, vascular bundle. 
them chemical defense against pathogens, herbivory and ultraviolet radiation (due to its antioxidant power) and an aid in the dispersal by birds (inducing regurgitation) (Roshchina \& Roshchina 1993; Von-Teichman \& VanWyk 1993; 1994; Aguilar-Ortigoza \& Sosa 2004; Castro \& Demarco 2008).

Another important feature in mesocarp is the elongation of cells located between the secretory ducts and the vascular bundles. These elongated cells were also observed by VonTeichman (1990). The cell divisions that occur in this region are responsible for the separation that occur between the vascular bundles and the ducts. In young stages we observe the secretory ducts and the vascular bundles very close. Furthermore, these cells are the main site of starch accumulation in the last stage of development, an energetic substance demanded by dispersers (Roth 1977).

According to the organization of the endocarp, Wannan \& Quinn (1990) proposed a classification of two kinds of pericarp for Anacardiaceae: (1) the Spondias type with endocarp comprising a mass of sclerenchyma with irregular orientation and (2) the Anacardium type with endocarp in layers, comprising a lignified outer epidermis and parenchyma arranged in layers, including sclereids in palisade. Thus, the characteristics of the T. guianensis endocarp fall under the Spondias type. Von-Teichman (1990) studied the structure of the ripe fruit of $T$. guianensis and found that the endocarp is not massive, but relatively thin in comparison to another species of the same tribe, i.e., Lannea discolor Engl. (Von-Teichman 1987). We not report the presence of operculum, which agrees with the observations of Von-Teichman (1990). Moreover, the T. guianensis endocarp is considered sensu lato since the fully developed fruit includes the sclerified layers derived from the inner mesocarp. A novel aspect observed in T. guianensis is the presence of a secretory endocarp in unripe fruits. The production of hydrophilic mucilages by the endocarp may facilitate seed hydration (Western 2012). In cases in which the mucilage covers the seed, such as in Euphorbia species, the mucilage may mediate germination under waterlogged conditions, prevent seed predation by adherence to soil and promote seed dispersal by attachment to animals (Demarco \& Carmello-Guerreiro 2011; Western 2012). These mucilages are acids or neutral complex polysaccharides of high molecular weight (Fahn 1979) that undergo substantive swelling upon hydration (Western 2012). The production of lipids may be an important chemical defensive against fungi and other microorganisms (Fahn 1979). As described for Heeria angentea (Von-Teichman \& Wan-Wyk 1996), in T. guianensis the parenchymatous cells of the endocarp is replaced by a sclerenchymatous endocarp at the last stage of fruit development. According to Von-Teichman (1990), the endocarp hardening can be related to the seed protection for seeds lacking a mechanical protective layer. The secretory endocarp is naturally replaced by a sclerenchymatous endocarp, once the seed has not a mechanical protective layer (Von-Teichman 1990).

\section{Conclusions}

The results described herein suggest that fruits of T. guianensis have several characteristics related to fruit protection against pathogens and predators due to the presence of ducts secreting gum-resin, idioblasts containing phenolic substances and druses widely distributed in the mesocarp. The substances produced by the endocarp in young stages may play an important role in seed dispersal and germination. The presence of a secretory endocarp is first reported in the family.

\section{Acknowledgements}

We thank CNPQ (National Council for Scientific and Technological Development) for the master's scholarship granted to Elisabeth E. A. Dantas Tölke during the first few months of the development of this work and FAPESP (São Paulo Research Foundation) for the master's scholarship and technical reserve (Process 2011/02293-0). We also thank the FAPESP for their additional financial support (FAPESP 01/12178-1, 03/13556-5, 14/18002-2, Biota/ FAPESP 96/12345-5, 00/12469-3).

\section{References}

Aguilar-Ortigoza CJ, Sosa V. 2004. The evolution of toxic fenolic compounds in a group of Anacardiacee genera. Taxon 53: 357-364.

Barroso GM, Peixoto AL, Ichaso CLF, Guimarães EF, Costa CG. 2007. Sistemática de Angiospermas do Brasil. 2nd. edn. Vol. 2. Viçosa, UFV.

Bennici A, Tani C. 2004. Anatomical and ultrastructural study of the secretory cavity development of Citrus sinensis and Citrus limon: evaluation of schizolysigenous ontogeny. Flora 199: 464-475.

Cain AJ. 1947. The use of Nile Blue in the examination of lipids. Quarterly Journal of Microscopical Science 88: 383-392.

Calvo TR, Demarco D, Santos FV, et al. 2010 Phenolic compounds in leaves of Alchornea triplinervia: anatomical localization, mutagenicity, and antibacterial activity. Natural Product Communications 5: 1225-1232.

Carmello-Guerreiro SM, Paoli AAS. 2000. Estrutura do pericarpo e da semente de Astronium graveolens Jacq. (Anacardiaceae) com notas taxonômicas. Revista Brasileira de Botânica 23: 87-96.

Carmello-Guerreiro SM, Paoli AAS. 2002. Ontogeny and structure of the pericarp of Schinus terebinthifolius Raddi (Anacardiaceae). Brazilian Archives of Biology and Technology 45: 73-79.

Carmello-Guerreiro SM, Paoli AAS. 2005. Anatomy of the pericarp and seed-coat of Lithraea molleoides (Vell.) Engl. (Anacardiaceae) with taxonomic notes. Brazilian Archives of Biology and Technology 48: 599-610

Castro MM, Demarco D. 2008. Phenolic compounds produced by secretory structures in plants: a brief review. Natural Product Communications 3: $1273-1284$.

Corrêa MP. 1978. Dicionário das plantas úteis do Brasil e das exóticas cultivadas. Vol. 5. Rio de Janeiro, MINAGRI/IDBF.

Demarco D, Carmello-Guerreiro SM. 2011. Pericarp ontogeny and histochemistry of the exotesta and pseudocaruncle of Euphorbia milii (Euphorbiaceae). Rodriguésia 62: 477-489.

Dong Z, Bass P. 1993. Wood anatomy of trees and shrubs from China. V. Anacardiaceae. IAWA Journal 14: 87-102.

Fahn, A. 1979. Secretory tissues in plants. London, Academic Press.

Fisher DB. 1968. Protein staining of ribboned epon sections for light microscopy. Histochemie 16: 92-96. 


\section{Pericarp ontogeny of Tapirira guianensis Aubl. (Anacardiaceae) \\ reveals a secretory endocarp in young stage}

Furr M, Mahlberg PG. 1981. Histochemical analyses of laticifers and glandular trichomes in Cannabis sativa. Journal of Natural Products 44: 153-159.

Ganter P, Jollés G. 1969. Histochimie normale et pathologique. Vol. 1. Paris, Gauthier-Villars.

Ganter P, Jollés G. 1970. Histochimie normale et pathologique. Vol. 2. Paris, Gauthier-Villars.

Gerrits PO, Smid L. 1983. A new, less toxic polymerization system for the embedding of soft tissues in glycol methacrylate and subsequent preparing of serial sections. Journal of Microscopy 132: 81-85.

González AM, Vesprini JL. 2010. Anatomy and fruit development in Schinopsis balansae (Anacardiaceae). Anales del Jardín Botánico de Madrid 67: 103-112.

Gregory M, Baas P. 1989. A survey of mucilage cells in vegetative organs of the dicotyledons. Israel Journal of Botany 38: 125-174.

Johansen DA. 1940. Plant Mycrotechnique. New York, McGraw-Hill Book.

Lacchia APS, Carmello-Guerreiro SM. 2009. Aspectos ultra-estruturais dos canais secretores em órgãos vegetativos e reprodutivos de Anacardiaceae. Acta Botanica Brasilica 23: 376-388.

Lacchia APS, Tölke, EEAD, Carmello-Guerreiro SM, Ascensão L, Demarco D. 2016a. Foliar colleters in Anacardiaceae: first report for the family. Botany 94: 337-346

Lacchia APS, Tölke, EEAD, Demarco D, Carmello-Guerreiro SM. 2016b. Presumed domatia are actually extrafloral nectaries on leaves of Anacardium humile (Anacardiaceae). Rodriguesia 67: 19-28.

Lenza E, Oliveira PE. 2005. Biologia reprodutiva de Tapirira guianensis Aubl. (Anacardiaceae), uma espécie dioica em mata de galeria do Triângulo Mineiro, Brasil. Revista Brasileira de Botânica 28: 179-190.

Li JX, Baskin JM, Baskin CC. 1999. Pericarp ontogeny and anatomy in Rhus aromatica Ait. and R. glabra L. (Anacardiaceae). Journal of the Torrey Botanical Society 126: 279-288.

Lillie RD. 1965. Histopathologic technic and practical histochemistry. 3 rd. edn. New York, McGraw-Hill Book.

Lorenzi H. 2002. Árvores brasileiras: manual de identificação e cultivo de plantas arbóreas nativas do Brasil. 4 th. edn. São Paulo, Instituto Plantarum de Estudos da Flora.

Machado SR, Carmello-Guerreiro SM. 2001. Estrutura e desenvolvimento de canais secretores de Schinus terebinthifolius Raddi (Anacardiaceae). Acta Botanica Brasilica 15: 189-195.

McManus JFA. 1948. Histological and histochemical uses of periodic acid. Stain Technology 23: 99-108.

Metcalfe CR, Chalk L. 1950. Anacardiaceae. In: Metcalfe CR, Chalk L. (eds.) Anatomy of the dicotyledons. Vol. 2. Oxford, Clarendon Press. p. 244-248

Monteiro WR, Castro MM, Fahn A, Caldeira W. 1995. Observations on the development of the foliar secretory cavities of Porophyllum lanceolatum (Asteraceae). Nordic Journal of Botany 15: 69-76.

Monteiro WR, Fahn A, Caldeira W, Castro MM. 1999. Ultrastructural observations on the foliar secretory cavities of Porophyllum lanceolatum DC. (Asteraceae). Flora 194: 113-126.

O'Brien TP, Feder N, Mccully ME. 1964. Polychromatic staining of plant cell walls by toluidine blue O. Protoplasma 59: 368-373.

Pearse AGE. 1980. Histochemistry theoretical and applied preparative and optical technology, 4 th. edn. Edinburgh, Churchill Livingston.

Pell SK, Mitchell JD, Miller AJ, Lobova TA. 2011. Anacardiaceae. In: Kubitzki K. (ed.) The families and genera of vascular plants: X. Flowering Plants. Eudicots. Sapindales, Cucurbitales, Myrtales. Berlin, Springer. p. 7-50.
Piennar ME, Von-Teichman I. 1998. The generic position of Lithraea brasiliensis Marchand (Anacardiaceae): evidence from fruit and seed structure. Botanical Journal of the Linnean Society 126: 327-337.

Pizzolato TD, Lillie RD. 1973. Mayer's tannic acid-ferric chloride stain for mucins. The Journal of Histochemistry and Cytochemistry 21: 56-64.

Ribeiro JF, Walter BMT. 1998. Fitofisionomias do bioma cerrado. In Sano SM. Almeida SP. (eds.) Cerrado: ambiente e flora. Planaltina, Embrapa-CPAC. p. 89-166.

Rickson FR, Rickson MM. 1998. The cashew nut, Anacardium occidentale (Anacardiaceae), and its perennial association with ants: extrafloral nectary location and the potencial for ant defense. American Journal of Botany 85: 835-849.

Rodrigues TM, Santos DC, Machado SR. 2011a. The role of the parenchyma sheath and PCD during the development of oil cavities in Pterodon pubescens (Leguminosae-Papilionoideae). Comptes Rendus Biologies 334: 535-543.

Rodrigues TM, Teixeira SP, Machado SR. 2011b. The oleoresin secretory system in seedlings and adult plants of copaiba (Copaifera langsdorffii Desf., Leguminosae-Caesalpinioideae). Flora 206: 585-594.

Roshchina VV, Roshchina VD. 1993. The excretory function of higher plants. Berlin, Springer-Verlag.

Roth I. 1977. Fruits of angiosperms. Berlin, Grebuder Borntraeger.

Santana WMS, Silva-Mann R, Ferreira RA, Arrigoni-Blank MF, Blank A, Poderoso JCM. 2009. Morfologia de flores, frutos e sementes de paupombo (Tapirira guianensis Aublet. - Anacardiaceae) na região de São Cristóvão, SE, Brasil. Scientia Forestalis 37: 47-54.

Spjut RW 1994. A systematic treatment of fruit types. New York, The New York Botanical

Garden.

Tropicos. 2016. Tropicos Home. Missouri Botanical Garden. www.tropicos. org. 30 Jun. 2016.

Venning FD. 1948. The ontogeny of the laticiferous canals in the Anacardiaceae. American Journal of Botany 35: 637-644.

Von-Teichman I. 1987. Development and structure of the pericarp of Lannea discolor (Sonder) Engl. (Anacardiaceae). Botanical Journal of Linnean Society 95: 125-135.

Von-Teichman I. 1990. Pericarp and seed coat structure in Tapirira guianensis (Spondiadeae: Anacardiaceae). South African Journal of Botany 56: 435-439.

Von-Teichman I, Van-Wyk, AE. 1993. Ontogeny and structure of the drupe of Ozoroa paniculosa (Anacardiaceae). Botanical Journal of the Linnean Society 111: 253-263.

Von-Teichman I, Van-Wyk AE. 1994. The generic position of Protorhus namaquensis Sprague (Anacardiaceae) - evidence from fruit structure. Annals of Botany 73: 175-184.

Von-Teichman I, Van-Wyk AE. 1996. Taxonomic significance of pericarp and seed structure in Heeria argentea (Thunb) Meisn (Anacardiaceae), including reference pachychalazy and recalcitrance. Botanical Journal of the Linnean Society 122: 335-352.

Wannan BS, Quinn CJ. 1990. Pericarp structure and generic affinities in the Anacardiaceae. Botanical Journal of the Linnean Society 102: 225-252.

Wendt T, Mitchell JD. 1995. A new species of Tapirira (Anacardiaceae) from the Isthmus of Tehuantepec, Mexico. Brittonia 47: 101-108.

Western, TL. 2012. The sticky tale of seed coat mucilages: production, genetics, and role in seed germination and dispersal. Seed Science Research 22: 1-25.

Wunnachit W, Jenner CF, Sedgley M. 1992. Floral and extrafloral nectar production in Anacardium occidentale L. (Anacardiaceae): an andromonoecious species. International Journal of Plant Science 153: $413-420$ 